\title{
WORLDVIEWS, THE PROBLEM OF EVIL, AND RATIONAL DISCOURSE: THOUGHTS ON THE FRAMEWORK OF STUMP'S DEFENCE
}

\author{
GEORG GASSER
}

University of Innsbruck

\section{A BRIEF EXPOSITION OF THE PROBLEM OF EVIL}

Most Christian traditions embrace the view that our world was created and is governed by an omniscient, omnipotent, and morally perfect God. Undeniably, our world is also a place full of heart breaking human and non-human suffering. The extensive amount of suffering and its apparently random distribution make it hard to believe that the world was created and is governed by an omniscient, omnipotent, and morally perfect God.

There are different versions of the problem of evil. The contemporary debate prominently features the distinction between the Logical Problem of Evil and the Evidential Problem of Evil. The former claims that the existence of God is logically incompatible with a world full of apparently gratuitous suffering. The latter claims that, although the existence of suffering and God are not logically incompatible, there is little reason to believe in God in light of all the suffering in the world. The idea is that the vast amount of suffering in our world makes it very unlikely that there is a plausible explanation for why God would create such a world. Rather, suffering provides strong evidence that there is no God.

Eleonore Stump's Wandering in Darkness (WID) is primarily concerned with the second problem. As she states at the outset, it is highly debatable whether God has morally sufficient reasons to allow suffering (WID, p. 4). Her book is an attempt to defend the claim that God has morally sufficient reasons for doing so. 
In this paper I deal with the explanatory scope of Stump's defence as laid out in WID. I focus on two worries which Stump's critics might raise:

(i) The first worry is that a defence is too explanatorily weak. A more 'offensive' account would be needed to persuade an atheist that theism might be a viable and not just a consistent position in the light of the suffering in the world.

(ii) The second worry is that a defence appears to be directed foremost at believers by rebutting an attack on certain claims of their faith, instead of at persuading non-believers that their view is false.

I will discuss these worries in the following way: With the aid of the notion of worldview, first I clarify the argumentative context of Stump's defence. After that I explain why hardly more can be expected than a defence when it comes to a discussion among adherents of different worldviews about issues such as the problem of evil; this addresses the first worry. This conclusion might disappoint some, but my discussion should show, in answer to the second worry, that the main purpose of a defence is not to produce conversions. The main aim of a defence is to illustrate that the Christian understanding of God is intellectually defensible - despite all the suffering in the world. I conclude that Stump's defence fulfils this explanatory purpose. There is hope that our wandering in darkness once will end up in light.

\section{WHAT A DEFENCE IS ABOUT}

Stump is deliberate about noting that her account is a defence, not a theodicy (WID, pp. 19-20). Generally a defence is understood to be a theory which describes a possible world similar to ours containing God and suffering and which presents morally sufficient reasons for God's allowing suffering in the possible world in question. A defence differs from a theodicy in that it does not claim that the possible world is identical to the actual one. Thus, on the one hand, a defence does not claim to present God's real reasons for allowing suffering in the world. On the other hand, however, it does not exclude the possibility of doing so either. The possible world of a defence, by being similar to ours, might coincide with the latter. Hence, a defence aims at offering a story at least about God's possible reasons for allowing suffering in our world, thereby rebutting the attack from the evidential problem of evil. Ideally this story should not be merely coherent but also plausible; that is, someone hearing the story should have good reasons to think that the story might be true. 
It is important to keep in mind that a defence provides a general explanatory theory about God's possible sufficient reasons for allowing suffering in the world. It does not aim to explain particular instances of the suffering of any real person. A defence accounts for rational belief in God and not for a causal explanation of particular instances of suffering.

\section{IS STUMP'S DEFENCE A FAILURE?}

A critic of defences might demur that a defence does not quite give us what most people would expect because it gives us too little. In his paper, Fischer, for instance, presents a story which he calls a 'spare defence'. It is a story about God's using a certain 'matrix' to apportion happiness in heaven in relation to the evil suffered on earth. The more someone suffers unjustly in his earthly life, the more happiness is assigned to him in the afterlife (one might think of the biblical story of the rich man and Lazarus in Luke 16: 14-31). The compatibility of God's existence with human suffering is secured and there is no strong reason to think that Fischer's account is false or incompatible with uncontested empirical evidence of the actual world. Assuming that Fischer's account fulfils the adequacy criteria for being a defence, such as logical consistency, coherence, and compatibility with empirical evidence, it nevertheless appears to be a 'really unsatisfying' story. ${ }^{1}$

One reason for Fischer's dissatisfaction is that, if his spare defence is a defence, then probably many more stories would qualify as defences as well. If this is the case, one might wonder what Stump's 'richer and more detailed account adds' ${ }^{2}$ to simpler and more straightforward defences such as Fischer's. His suspicion is that the quality bar for a defence is set too low as long as it merely has to fulfil the adequacy criteria mentioned above.

A similar worry also appears to be raised by Paul Draper in his review of Stump's book. ${ }^{3}$ According to him, certain instances of suffering remain hard to explain even if one accepts the general thrust of Stump's argument. Amongst others, Draper refers to worse psychological health due to suffering, animal suffering, and forms of trivial suffering with no

\footnotetext{
${ }^{1}$ John Martin Fischer, 'Struggling With Evil: Comments on Wandering in Darkness', European Journal for Philosophy of Religion 4/3 (2012), p. 115.

${ }^{2}$ Fischer, 'Struggling With Evil', p. 117.

${ }^{3}$ Paul Draper, 'Wandering in Darkness: Narrative and the Problem of Suffering', Notre Dame Philosophical Reviews, <http://ndpr.nd.edu/news/24772-wandering-in-darknessnarrative-and-the-problem-of-suffering/> [accessed 03/09/2012]
} 
apparent psychological impact. I don't want to discuss these points here. Crucial for the present discussion, however, is Draper's emphasis that Stump's defence becomes less and less likely to be true if these instances of suffering cannot be accommodated within her account - even if it cannot be shown that they are inconsistent with it. For dismissing a defence it is not required to prove it is false; it suffices to show that it cannot solve various challenging aspects of the evidential problem of evil.

Both critiques boil down to the claim that it is one thing to come up with a story about a possible world containing God and suffering which apparently is not false. It is another thing, however, to come up with a story about a possible world containing God and suffering which probably is also true. As long as a defence merely fulfils adequacy criteria such as internal and external consistency, developing one seems to be more an endeavour of creative storytelling and theory construction in the light of present empirical knowledge than the well-grounded business of providing good reasons for belief to non-believers. A quite improbable but consistent story is not enough for showing that her advocates face no evidential problem of evil. Hence, according to this line of thought, a defence should be considered to be a failure if it does not offer enough evidence to remove major obstacles to believing (such as the evidential problem of evil) and to convince a non-believer that theism really is a serious alternative to a non-theistic understanding of reality.

If this reading is correct, then I take it that this critique advocates making defences into something closer to what Stephen T. Davis once called a hard apologetic argument. For Davis, this is an argument that attempts to demonstrate that it is more rational to hold a given belief than not holding it in its modest form, and that it is irrational not holding it in its strong form. A soft apologetic argument, instead, attempts to demonstrate that one is within his intellectual rights in holding a given belief. ${ }^{4}$

I'll argue in the next section, however, that a version of a hard apologetic argument or anything close to it is difficult or almost impossible to put forward successfully, for reasons pertaining to the worldview of the person to whom the argument is presented. If this is the case, then the proponent of a defence shouldn't be overly concerned with the worry raised by Fischer and Draper, because, though well intentioned, it misses the mark.

${ }^{4}$ See Stephen T. Davis, Risen Indeed. Making Sense of the Resurrection (Grand Rapids: Eerdmans, 1993), p. 1. 


\section{THE CONCEPT OF A 'WORLDVIEW'}

Stump suggests that the problem of suffering is embedded in a larger conflict over divergent interpretations of our world, one theistic, the other atheistic. She writes:

The picture theodicy paints is meant to show us God and human beings in such a light that we can begin to see the compatibility of God and human suffering in our world. The picture offered by opponents of theodicy, on the other hand, presents the world in such a way that some defect of mind or character (or both) would be required to believe that the world included God as well as suffering. (WID, p. 18)

Unfortunately, Stump does not develop this remark further. Her quote suggests, however, that the 'natural place' for the problem of suffering is in a dialogue between adherents of different worldviews. In this section I develop this point by elaborating on the notion of a worldview and reflecting on its role in a person's life.

Sometimes philosophers refer to different metaphysical worldviews as a source of disagreement about a specific claim. Davis, for instance, underlines that a vital factor for an adequate understanding of the discussion about the possibility of the resurrection is to take into consideration the different basic metaphysical claims typically held by those who believe and those who do not believe in the resurrection. The non-believer's worldview can be circumscribed roughly as a naturalistic understanding of reality whereas the believer's worldview contains at least one additional item to the naturalist's worldview, namely God (and as a consequence God's interaction with the world). ${ }^{5}$

Davis's suggestion definitely goes in the right direction but I would like to supplement it additionally. Not only are basic metaphysical beliefs crucial for understanding a person's worldview, ${ }^{6}$ but rather all those beliefs which play a determining role in how we understand and interact with reality, be they anthropological, ethical, religious, aesthetic and so on.

Examples of such beliefs might be: 'All human beings have the same value.' 'The world can be best explained by the natural sciences.' 'Nothing that happens is meaningless.' 'Material entities do not suddenly dissolve

${ }^{5}$ Davis, Risen Indeed, pp. 17-18.

${ }^{6}$ The notion of worldview used here draws particularly on the work of Otto Muck. See, for instance, Otto Muck, Rationalität und Weltanschauung (Innsbruck: Tyrolia, 1999) and Otto Muck, 'J. M. Bochenski on the Rational Aspect of Weltanschauung', International Philosophical Quarterly, 52 (2012), 63-78. 
into air.' 'We continue to persist through time without interruption.' 'There is no afterlife.' 'Do not kill is the most important ethical imperative.' 'God is our father and we are all his beloved children.'

A person's worldview constitutes the framework, so to say, within which the person understands the world and interprets her existence and her individual experiences in a certain way: She may take reality to be a teleologically structured whole or a mere random collection of particles, she may interpret certain situations as meaningful or as meaningless, and she may emphasize certain experiences and de-emphasize others.

The beliefs a worldview consists of are operative at a rather global level for they interpret and integrate the single area-specific beliefs which a person holds into a structured whole. Against the background of her worldview, a person attempts to order and integrate her specific experiences and her individual area-specific beliefs into a more or less coherent system of beliefs, thus providing meaning and orientation for her as cognizer, decider, and agent. It should be clear by now that the beliefs a worldview consists of play a fundamental life-orienting role. ${ }^{7}$ They are not incidental beliefs which a person might change or abandon easily, for instance, in the light of new discoveries and facts.

The imagery of a web of beliefs might help us grasp more precisely the structure of a worldview. This imagery highlights that the more central a belief is, the more confident the person holding it is that it is true. As a consequence, the more central a belief is, the less inclined the person in question will be to reject or revise it if she discovers it to be inconsistent or in tension with her other less central beliefs.

Imagine two people, John and Mary. For Mary the belief that the Christian God exists (belief B, for short) is central to her worldview. She holds B with great confidence (and she has also reasons for holding this belief). The centre of John's worldview, instead, includes the belief that there is no God but that reality consists only of physical matter. If John confronts Mary with the belief that people do not rise from the dead because our scientific knowledge and common sense rules out such a possibility (belief $\mathrm{C}$, for short), and Mary realizes that $\mathrm{C}$ is in tension with $B$, then it is very likely that she will not accept $C$, because it is less central for her than B, and because she has also reasons to believe B. Mary might find John's arguments in favour of $\mathrm{C}$ persuasive, if considered in

${ }^{7}$ See also Patrick Riordan, 'Religion as Weltanschauung: A Solution to a Problem in the Philosophy of Religion', Aquinas, 34 (1991), 519-534. He refers to 'life-carrying convictions' for the underlying of this insight. 
itself, but might nevertheless maintain $\mathrm{B}$ because the strength of her belief that B outweighs her confidence in C. She might say: 'John is most likely right if we consider his claim from a purely scientific perspective. Then dead people do not come back to life. I am a theist, however, and given what I take myself to know about God, and given my personal belief, I am confident and have good reasons to believe that God will raise us from the dead.'

The upshot of this discussion is that all people interpret their beliefs and experiences within a certain framework, that is, their worldview. Depending on which beliefs are found at the centre of a person's worldview, other beliefs are found more or less plausible. Mary is convinced of her position not primarily because the arguments in favour of $\mathrm{B}$ are stronger than the arguments in favour of $\mathrm{C}$ but because her theistic worldview entails also the belief that God can raise people from the dead, that is, not-C. Whether Mary rejects $\mathrm{C}$ relies, at least in part, on how central B is in her overall belief set. What is consistent with one's most central beliefs is regarded by a person as a valid guiding principle for determining what is true and hence for guiding one's life.

It is important to note that this characterization of worldview is not committed to relativism about worldviews. A worldview is not merely an accumulation of subjective opinions, nor is it immune to rational criticism. Rather, a worldview is a system of beliefs which are subject to rational assessment and reconstruction. Muck distinguishes four criteria for assessing worldviews. The first two criteria refer to the internal structure of a worldview, the last two criteria to the 'material' at which a worldview is directed. ${ }^{8}$

The first criterion is consistency, that is, a worldview has to be free of contradiction. The second criterion is coherence, that is, a worldview should be a unified and coordinated interpretative system and not merely be a loose collection of rather independent subsystems. Thirdly, a worldview must refer to experience in general because it has to interpret and evaluate the various experiences of a person. Finally, a worldview has to be open to new experiences and facts, that is, it has to consider all possibly relevant data in principle and exclude nothing arbitrarily - for instance, because it might count as evidence against one's actual worldview. ${ }^{9}$

\footnotetext{
${ }^{8}$ He adopts these criteria from Frederick Ferré, Language, Logic and God (New York: Harper \& Row, 1961).

${ }^{9}$ These criteria are not exclusively pertaining to worldviews. The quality of scientific theory can also be examined along these lines.
} 
The crucial point is that these criteria make it possible to compare and contrast people's worldviews, and to rationally assess any needs for changes and adaptions. An intellectually honest dialogue partner will aim at observing these criteria in order to recognize errors and deficiencies in her own worldview which would impair its overall structuring and integrative function.

\section{ARGUING ABOUT SPECIFIC CLAIMS WITHIN THE CONTEXT OF DIVERGENT WORLDVIEWS}

Stump notes that there are at least two possibilities for proceeding in a situation of conflict among adherents of different worldviews:

Sometimes the thing to do with such a divergence of views is to try to adjudicate the truth or falsity of the claims particularly important to it. [...] In other words, we could argue through each claim [...], in order to try to establish the truth of our position. But another thing we could do would be to describe [...] our own worldview [...]. In presenting these views [...], we would not be arguing for the truth of our own claims [...] but rather showing [...] the worldview within which those claims are embedded. (WID, p. 18)

Stump's first suggestion is to assess the truth of each controversial claim. Her second suggestion is to explain in detail one's worldview so that an 'empathic understanding' becomes possible for the discussion partner. I will discuss both possibilities in turn.

Generally a rational person will accept a claim on the basis of a good argument, because she aims to have true beliefs and to avoid false ones. Certain psychological attitudes like indolence, fear, or stubbornness might prevent a person from doing so, but this person is presumably not acting like a fully rational or epistemically virtuous agent.

Psychological barriers, however, are not the only reasons which might prevent a person from accepting a claim on the basis of a good argument. If the foregoing reflections about the role of a person's worldview are correct, then a person might reject the conclusion drawn from a good argument because she is already strongly convinced in virtue of her worldview that the conclusion is false. ${ }^{10}$

\footnotetext{
${ }^{10}$ My argumentation is to a large extent congenial to Davis's Risen Indeed, pp. 15-20. I found also Jennifer Faust's discussion on these issues very helpful and illuminating. See Jennifer Faust, 'Can religious arguments persuade?', International Journal for Philosophy of Religion, 63 (2008), 71-86. Both authors' work complements Muck's thoughts nicely.
} 
Unlike the person with psychological barriers, the latter person's conclusion is not irrational. Rather, it makes perfect sense given her worldview. Because her worldview determines what she takes to be good evidence, an argument which might strike someone else as persuasive might lack any force for a person whose worldview does not recognize the force of this argument. As mentioned above, the confidence which one has in one's worldview is likely to outweigh one's confidence in a specific claim which is in tension with or even contradicting one's worldview. The person is rational in case it does because, given her worldview, she has reasons to assume that the specific claim in question is most probably wrong.

If Mary's worldview includes 'God exists' as a central belief, then the problem of suffering must not rationally compel Mary to change her mind. Mary will continue to believe in God, if this belief frames her understanding of the arguments put forward by her opponents. The problem of suffering combined with scientific knowledge about cosmology and evolutionary biology, taken by itself, might provide a strong case against theism. Mary can see this point put forward by her atheist interlocutor. But once this argument is placed within Mary's theistic worldview, it loses much of its force, because this evidence against theism is undermined by the other evidence with which Mary's theistic worldview provides her. The standard for evaluating the evidence against theism changes, so to speak, because it is not viewed from a neutral perspective anymore but rooted in her theistic worldview. The reason why Mary rejects the conclusion of the evidential problem of suffering is not that she thinks that the evidence for it is weak. Rather, her theistic worldview prevents the problem of suffering from undermining her belief in God by providing evidence in favour of theism which is stronger than the evidence, provided by suffering, against theism.

For someone without a theistic worldview, by contrast, the problem of suffering has great force indeed against the claim that God exists. For such a person all the suffering in the world provides strong evidence that there is no morally perfect supreme being. And there is nothing wrong if a non-believer is reasoning in this way. Hence, from the same facts ('There is much suffering in the world.') and experiences ('I suffered in my life a lot.') can be drawn rather different conclusions in the light of divergent worldviews.

Of course, the firmness of one's worldview should not be overstated. As indicated in the discussion about the criteria of rationality for worldviews, 
Mary might undergo unexpected experiences which affect her so profoundly that she cannot integrate them in her worldview anymore and as a consequence loses her faith. Or she might be confronted with so much persuasive counter-evidence to her worldview that this leads her to think that it is rational to give it up. In a less extreme case Mary might feel the need to re-evaluate her prevalent belief system. At the end of this process she might become more receptive to arguments she did not consider before and certain claims of her atheistic interlocutors may be more convincing to her than they were before. Certain beliefs which were at the outer periphery of her web of beliefs now move closer towards the centre, so to speak, and hence play a greater role in impacting any new beliefs which she may form. The above mentioned discussion of Mary with John might be either of such a case.

The conclusion drawn from these reflections is that single claims and arguments, even if probable in themselves, will generally fail to convince a person if these claims are incompatible with the central beliefs of her worldview. This attitude becomes understandable once we realize that a person's worldview determines how plausible she finds counterarguments to be. Jennifer Faust underlines this point and argues that many arguments for religious claims are likely to commit what she calls 'begging the doxastic question'. On Faust's account a person begs the doxastic question just in case she 'would find the argument persuasive only if she antecedently believes the argument's conclusion.. ${ }^{11}$

Thus, a person's worldview affects how plausible a person finds arguments against her worldview: if she finds them implausible, it is because her worldview does not incorporate them. If this argumentation is correct, then it does not seem to be a very promising way to assess the truth and soundness of individual arguments against a person's worldview. Since a theist and an atheist interlocutor have, in a fundamental sense, a different understanding of reality, they attribute different argumentative force to the specific arguments pertaining to the problem of suffering. As a consequence, there is no neutral ground available where an 'objective' evaluation of these arguments detached from one's worldview can be undertaken and weighed up against one another.

\footnotetext{
${ }^{11}$ Faust, 'Can Religious Arguments Persuade?', p. 80.
} 


\section{THE ROLE OF A DEFENCE WITHIN THE CONTEXT OF DIVERGENT WORLDVIEWS}

According to the second possibility Stump mentions, one can describe one's worldview in great detail, to help one's interlocutor understand it. Stump adopts this approach for her defence. The primary aim of this procedure is to explain one's worldview. The question of truth and falsehood might come in later but does not play a primary role in this account.

The basic idea is that Mary communicates to her interlocutor not just that she holds certain central beliefs, but also her reasons for believing them; how her worldview structures and guides her life; and what biographically brought her to believe it. If Mary describes her worldview in this way, then her interlocutor has the chance to see the world, so to speak, through Mary's eyes. The worldview is not an abstract set of beliefs anymore but it becomes 'experiencable' from the interlocutor's subjective perspective. ${ }^{12}$

The objective of this imagined dialogue is neither a conversion of Mary's interlocutor nor a demonstration that the interlocutor's view is illfounded. Rather, it is to enable the interlocutor to gain an empathic access to Mary's worldview, as well as to elucidate the various interconnections within it. Ideally this results in a second-personal and holistic access to the Lebenswelt of one's interlocutor. The primary objective is for the discussion to result in a deepening of mutual understanding between both parties. Stump writes:

[...] the defense will deepen the discussion between the proponents of the argument from evil and the presenters of the defense, because the defense will show the difference in worldview between the two groups, so that the discussion can be more fruitfully focused on the underlying sources of disagreement. (WID, p. 20)

In addition, this procedure is helpful for the person describing her worldview, because it helps her to explicate it and to see more clearly her reasons and experiences supporting the issue under debate (as well as any which may not support it, of course). Hence, a defence gives Mary the opportunity to uncover reasons for her view which she might have missed before, and it might also show some of her reasons to be bad ones. Thanks to the defence, she might move from a belief based on weak

12 This second-person account of knowledge is crucial for Stump's defence. See, for instance, WID, pp. 48-63. 
evidence to a belief based upon strong evidence and feel more justified in her belief that God and suffering can coexist. Finally, she might see more clearly than before connections and tensions within her worldview. One might say that the more precisely a person can articulate her own worldview, the less she needs a defence to back it up, and the less clearly she can articulate it, the more a defence can help make it more robust and well-grounded.

One might see now why it comes as no surprise that the main impact of a defence of theism is directed at people holding a theistic worldview. Whether someone finds a defence plausible depends very much on her own worldview. An atheist might consider a defence such as Stump's as an interesting just-so story but she will not find it very plausible because her worldview does not contain the crucial premise that an omnibenevolent God exists.

As indicated already at the end of the former paragraph, it is likely, however, that the defence might sensitize the atheist to certain issues she was not aware of so far. The defence might initiate a thought process which could result in some restructuring of the atheist's worldview at the end. Thus, the conversion of the atheist interlocutor is an objective which extends beyond the direct aim for a defence. This is not to say that a defence cannot produce a conversion but any such result should be considered as an exception rather than the rule. It is probably more accurate to say that, in such a case, hearing a defence is a sort of trigger for the conversion of a person in whom the soil has already been prepared. On the level of the person's worldview this means that some peripheral beliefs in her worldview are moving more closely to the centre, and formerly central beliefs are losing confidence for the person.

Someone might object that this argumentation runs into an epistemic circle. ${ }^{13}$ The question is either whether God exists and hence no gratuitous evil exists or whether gratuitous evil exists and therefore God does not exist. Since a non-believer will hardly have any reasons to believe in God, she also has no reasons to interpret suffering in the world as purposeful. Since there is no such thing as a bare, non-interpreted, and objective stance for assessing our experiences, the way in which the atheist assesses suffering will inevitably depend largely on her worldview - that is, in our case, on whether she thinks there is a God or not.

${ }^{13}$ David McNaughton, 'From Darkness into Light? Reflections on Wandering in Darkness', European Journal for Philosophy of Religion 4/3 (2012), p. 133-134. 
In his paper, McNaughton suggests that one way out of this epistemic circle would be, for instance, for a person to acquire some independent grounds for believing in God and His goodness. One possibility would be to have a personal experience of God's omnibenevolence. If such an experience takes place, however, then this does not constitute one more piece of evidence for or against the existence of God, but shifts the evaluation of one's evidence clearly towards a theistic understanding of reality. Given that the framing of the debate about the problem of suffering impinges directly on issues concerning one's worldview, and assuming that the role of worldviews is more or less as indicated, then there is no use in looking for a neutral ground within the sphere of pure reason for starting the discussion or coming to a well-grounded conclusion.

This brings me back to the end of Draper's critique. There he asks how we should decide whether or not to believe a defence if it cannot be tested by objective evidence like a scientific theory or criminal case. In the light of the aforesaid, my suggestion is that one's personal worldview is the decisive factor for belief or non-belief. And at this point, as McNaughton indicates, one's personal experience of God's presence and goodness becomes essential. If a person makes such an experience, then in virtue of it an otherwise merely intellectually interesting and even beautifully narrated story turns, to a certain extent, into her own personal story. This might be reason enough for believing it is true - even if certain challenging questions remain unanswered.

No doubt, there is a sort of circularity involved here. The question is whether it is vicious. It is not an instance of committing the fallacy of circular reasoning in the sense of reasoning $\mathrm{p}$ is true because $\mathrm{q}$ is true and the truth of $\mathrm{q}$ is established on the basis of $\mathrm{p}$. Rather, it is closer to certain forms of circularity which appear to be unavoidable: We might define a person as a friend if he has good reasons to care for us and to take part in our life. It is not the case that a person first has reasons to care for me and then, in a second step, she becomes my friend. It seems more appropriate to say that by having these reasons to care for me she is my friend. Being a friend of mine consists in having good reasons to care for me. So we have circularity here, but it seems to be a benign form.

It should be noted, however, that circularity is not a feature pertaining exclusively to a religious point of view. It pertains to all issues being directly related to one's worldview, religious or not. I assume this helps to explain the starting point of our discussion - why non-believers worry 
that a defence such as Stump's does not provide enough evidence for coming to believe in God. The reasons are first, that non-believers do not share the central belief that there is a benevolent and caring God, and second, that there is no objective evidence available which would make it more rational to believe in than not believing in God.

Onceweunderstand the role of a worldview for a person's understanding and interpretation of reality, however, we are also in a position to more thoroughly appreciate the virtues and limits of a defence along Stump's lines. A defence aiming at more than showing the coherence, rational defensibility, and plausibility of a believer's perspective on reality would miss the fundamental role which the worldview plays for the participants in this debate. Stump notes, that the 'plausibility is very much in the eye of the beholder' (WID, p. 20). I suggest that is as it should be when it comes to issues so tightly bound up with one's worldview.

\section{TWO ISSUES AT THE VERY END}

There are two issues I would like to raise at the end. They can be seen as examples of how a defence can acquire the function of sensitizing the person reading it to certain problems. Stump's defence encouraged me to think more thoroughly about these issues, and I would thus like briefly to present them here.

Here is the first issue: Stump formulates two constraints which must be in place for suffering to be justified. First, there must be a benefit in terms of justification and/or sanctification, which outweighs the suffering. Second, this benefit could not have been achieved just as well in another way, that is, without this specific process of suffering. Stump writes:

A morally sufficient reason for God's allowing suffering must therefore be something that somehow defeats the badness of suffering so understood. [...] On the Thomistic defense, the benefit defeating a person's suffering has to do either with enabling a person to have the best thing for human beings or with enabling him to ward off the worst thing for human beings; [...]. (WID, p. 455)

The protagonists in the biblical narratives examined by Stump illustrate this point. According to Stump their suffering is redeemed because ' $[w]$ hat one cares about and loses becomes the best means available in the circumstances for finding and having what is infinitely more worth caring about than what is lost'. (WID, p. 478) 
If suffering turns out to be a necessary means for achieving a great good which could not be achieved without this specific suffering, then, one wonders, what happens to people who do not undergo experiences of deep suffering? This is not to say that these people will not experience such suffering as broken relationships, being disappointed by close friends, losing a loved one, etc. Such experiences are an integral part of the human condition. However, they might not have the deeply disturbing sort of suffering which touches the very centre of a person's existence, like the sufferings of the biblical figures Stump analyses. Consequently, it might be less likely that these 'more ordinary' forms of suffering yield a benefit such as justification and/or sanctification.

One immediate answer comes to mind: One could argue that there is no reason to think that these 'more mundane' forms of suffering are insufficient for entering into a process of justification and sanctification. They suffice because they are serious forms of suffering. What is decisive is that the sufferer allows herself to be refined through them and feels the need for redemption through God's salvific action. Someone enjoying her life and closing her heart to suffering will have a harder time recognizing that she is in need of redemption. If so, Stump's account can be read as a variation of the reminder of the biblical warning: 'Indeed, it is easier for a camel to go through the eye of a needle than for someone who is rich to enter the kingdom of God.' (Luke 18: 25) Suffering is, so to speak, an essential feature of one's way towards a deep relationship to God. The relationship to God does not take our suffering away; rather it makes our suffering not pointless.

At this point the other issue becomes virulent: One might claim that this understanding of suffering from a theistic view involves a form of bad faith. It aims at finding a rationale for something where no mitigating answer can be given because the universe is blind and deaf to the cries of the afflicted.

What can a theist say about this? First, a theist should underline that her worldview does not gloss over suffering at all. Rather, it takes human suffering as seriously as it can be taken. This becomes particularly clear if one considers Christianity. At the very centre of the Christian worldview stands the passion and death of Jesus Christ, the Son of God himself. His passion can be interpreted as the most profound and extensive suffering which eclipses any other instance of human suffering 
throughout history. ${ }^{14}$ Thus, it would be a deep misconception and unfair to accuse (Christian) theism of being callous towards the suffering of human beings.

However, taking suffering seriously is just one side of the story. The other side refers to the hope for reparation and justice for those suffering through God's salvific acts, albeit not in full until in the afterlife. This leads to the following thought: There is reason to think that the hope for healing and justice is not merely the expression of a religious attitude but it seems to be internal to the moral point of view. Innocent suffering cries out for restoration, healing and justice. The moral point of view says that this should be so. Of course, this internal disposition in human beings for justice does not entail that there will be any justice at the end. But if one embraces the view that the universe is indifferent to justice then one might wonder whether it is rational to care less about morality. Recently, Mark Johnston made this point. ${ }^{15} \mathrm{He}$ is no theist, but he is aware that a theistic worldview contains the resources to argue that justice will be achieved one day because each human being matters so much to God that no instance of suffering will pass unheeded. This makes it rational to choose the good and to shun the evil because the universe we inhabit is morally coherent.

An atheist, however, appears to remain empty handed: Interpreting the human race as a mere by-product of a series of cosmic accidents which occupies an infinitesimally small section of the vast cosmos does not make it reasonable at all to consider our fate as important as we usually are inclined to do. Within the universe we are so miniscule that the pursuit of our own and our fellow human beings' welfare does not matter because our very existence does not matter. This line of reasoning suggests that the importance of our moral reasons derives not merely from the moral point of view itself but is also dependent upon the interpretation of the universe and our position in it. Johnston writes that man 'should hope that it is a universe in which the cries of great injustice to be punished, and the cries of great sacrifice in the name of the good

${ }^{14}$ See e. g. Stump's interpretation of Jesus' cry of dereliction. Eleonore Stump, 'Atonement and the Cry of Dereliction from the Cross', European Journal for Philosophy of Religion, 4/1 (2012), 1-17.

${ }^{15}$ See Mark Johnston, Surviving Death (Princeton: Princeton University Press, 2010), pp. 8-12. Johnston considers this as a worrisome feature of atheistic naturalism, which was one of the main motivations for writing this book. 
to be rewarded, do not just echo in the void. ${ }^{16}$ Atheism, however, seems to be unable to argue for such a universe where moral coherence exists.

Someone might reply that this hope is nothing but an expression of wishful thinking, and that if someone believes in such a universe, then fantasy is beating reason. Maybe this is true. But how can we know? What seems to be true, however, is that it is not so much a theistic but an atheistic attitude adding to the burden of the sufferers for the latter crushes any hope for ultimate justice and consolation.

Wandering in Darkness contributes to assuage the burden of sufferers. It presents a world where God has morally sufficient reasons for allowing human suffering - at least of mentally fully functional human adults. Of course, this illuminates only one segment of the panoply of human suffering. It raises the hope, however, that the wandering in darkness of all of us will end up in light - with no suffering anymore but pure joy instead.

Acknowledgement. This publication was made possible through the support of a grant from the John Templeton Foundation, grant \#15571 ("Analytic Theology"). The opinions expressed in this publication are those of the author and do not necessarily reflect the views of the Templeton Foundation.

${ }^{16}$ Ibid., p. 10. 